\title{
Digital Technologies in the Training of Psychologists in Vladivostok
}

\author{
Irina Gerasimova ${ }^{1, *}$ \\ ${ }^{1}$ Far Eastern Federal University, Mordovtseva str., 12, 690091 Vladivostok, Russia
}

\begin{abstract}
In the context of the information volumes continuous growth, the digitalization of education is considered a necessary tool for the modernization of the educational system. There is a pronounced specificity of training specialists in the various fields of science - natural, humanitarian, technical and exact. How does work differ in the different forms of training specialists - full-time and part-time. There are peculiarities, opportunities and traditions in every particular university. In this regard, the problem arises of the need to digitalize education, determining the measure, and sufficiency in each case. The functioning of the current digital educational environment is due to both the psychophysiological capabilities of the human body, moral and ethical principles. The purpose of the study is to identify the saturation of digital educational technologies in the process of full-time training of studentspsychologists and conflictologists at FEFU. Research methods: problematization, survey, observation. The author examines two components of digitalization at the university - the learning process, and its organization and concludes the sufficiency of the information technologies use in the training of psychologists and conflictologists at FEFU. The author also draws attention to the active use of technical means in the educational process - the formalization of education, which manifests itself in a decrease of students' motivation, loss of interest, involvement, "nonappropriation" of information. Prevents direct transfer of distance learning formats to full-time. Requests the need for informational support of teachers. Emphasizes attention to ensuring the high-quality functioning of technical means.
\end{abstract}

\section{Introduction}

Digital technologies, along with methodological and technical support, are a component of the digital educational environment of a modern university. As shown by O.F. Prirodova, A.V. Danilova, A.N. Morgun, the concepts of the digital educational environment, electronic educational environment, information and educational environment in scientific research and regulatory documents governing educational activities in Russia are meaningfully correlated. In their opinion, the main function of the educational information

\footnotetext{
*Corresponding author: gerasimova.iv@dvfu.ru
} 
environment is to form educational trajectories, including the conditions of full-time education and self-education [1].

The digitalization of education is currently being carried out everywhere - from the United States, where this process has lasted for more than 60 years, to Myanmar, which belongs to low-income countries, but has already embarked on this path, developing education according to the British model $[2,3]$. This is a broad development of the educational information environment, including online learning, in the natural sciences. In particular, teachers from a university in Taiwan concluded that the POE study model they used to study the moon contributed to an increase in the level of critical thinking of students [4].

Great attention is paid to the digital educational environment in Russia: state policy is aimed at this, it is a kind of fashionable trend in dissertation research. Distance education is built on digital technologies. The growth rates of Russian online education are growing and there is a prospect of outstripping global ones [5]. Even a new term has appeared - smart didactics, which allows you to use cloud and blockchain technologies in targeted training [6]. Without the use of digital technologies, it is already impossible to present full-time education. But in this race for novelties, questions arise: at what level of digitalization we are, how much is needed, is there a measure and what is it for different forms of training (full-time, part-time, extramural) and directions (natural sciences, humanities, technical and exact).

At the same time, the attitude to the digital educational environment in the world is very ambiguous. As noted by D.G. Kochergin and E.E. Zhernov, distance education is practically absent in the elite private educational institutions of the United States, it is widespread in commercial universities only [2]. The economic breakthrough made in South Korea in recent decades, when a backward agrarian country turned into a leading world economy, a country that supplies high technologies, supertankers, according to various sources, is primarily associated with a high quality of education. At the same time, the Korean education system is considered one of the most successful in the world. The borrowed American model of education and Western values made it possible to carry out the "climb" in higher education. However, since 2014, the country has taken a course to return to the traditional oriental scientific approaches based on the national culture, philosophy, and language [7, 8]. In particular, it is difficult for the modern Korean to verbalize the learned essences when mastering hieroglyphs, i.e. for an accurate understanding, you need to pronounce, clarify the meanings [7]. Lectures at a Korean university are a discussion of teachers and students on a topic. And one of the first steps towards change was the return to open-ended examination questions [8].

Interest in humanitarian education in Russia in various social groups remains at a rather low level [9]. The analysis of the problematics of Russian-language publications on the issues of the digital educational environment allowed the researchers to come to the conclusion that the particular methodological aspects of studying the educational environment in Russia are encountered much more often than the general methodological ones [1].

So, the topic of the research carried out shows that not enough attention is paid to the digitalization of the training of students of the humanitarian profile, full-time education, as well as the concepts of organization, the psychological aspects of the functioning of the educational environment. The purpose of the study is to identify the saturation of digital educational technologies in the process of psychologists and conflictologists full-time training at the Far Eastern Federal University. The object of the research is digital technologies in education, the subject is digital technologies in the educational process of undergraduate psychologists and conflictologists of full-time undergraduate education. Methods: problematization, survey, observation. 


\section{Digitalization in the learning process and its organization}

The digital environment at the university is two interconnected components: the learning process and its organization. The use of digital technologies and technical means in the organization of training is regulated by federal educational standards in the direction of training. Since 2009, for the training of psychologists in the undergraduate program, the university had to provide all students with access to the electronic library system, which provides the possibility of individual access to the Internet, access to professional databases, information reference and search systems, to have public computer classes with connection to the Internet, multimedia projectors in all classrooms where lectures are held, to purchase licensed computer statistical systems for data analysis, as well as to have technical equipment for conducting workshops (audio and video equipment, video camera, voice recorder, etc.).

State standards also provide for the standards of technical means based on the number of students ${ }^{\dagger}$. After that, two more state educational standards were issued $(2014,2020)$, in which these requirements were expanded.

The FEFU administration strictly follows the instructions: all libraries, reading rooms, a methodological study, computer classes, classrooms are equipped with modern equipment. To form the basic skills of working in a digital environment, professional development is organized for teachers. The electronic environment has become a necessary and convenient tool in the organization of education: students and teachers use an electronic timetable, receive feedback in the form of a current assessment of their academic success in their account, their documents are presented in an electronic portfolio.

The technical equipment of the classrooms allows you to accompany the verbal form of training with a presentation, demonstration of video materials in online and offline modes, and videoconferences. The form of video conferencing turned out to be in great demand not only for external contacts but also for internal ones in the context of the spread of new coronavirus infection. If a teacher has difficulty, for example, when projecting material not on monitors, but on a large screen, technical support specialists provide remote assistance by telephone request.

However, based on the example of Vladivostok, it can be stated that not all universities have the technical component of education at such a high level, which is due to both the volume of funding and the profile of the university. That is, the provision of state, municipal and departmental universities is different. By the will of fate, it turned out that the author made a kind of travel in time: from the university, where the classroom fund was equipped in the old fashioned way and was very similar to the one in which he studied a long time ago, he ended up at the university, where they strive to meet the challenges every day.

There is no doubt - modern digital means is a necessary component of the educational process. However, from the first days, attention has fixed the differences in the organization of the study space in the classrooms: the teacher most often sits at his desk and speaks, controlling the computer while giving a lecture. Two different spaces are formed: the teacher on his own and the students on their own. When students go out to speak, they hold a phone/tablet or printed sheets with text, a presentation on the screen. At the same time, they stand close to the blackboard, that is, as far away from classmates as possible, who are

\footnotetext{
$\dagger$ Order of the Ministry of Education and Science of the Russian Federation of December 21, 2009 No. 759 "On the approval and implementation of the federal state educational standard of higher professional education in the field of training 030300 Psychology (qualification (degree)" bakalavr ")" (registered by the Ministry of Justice of the Russian Federation on February 3, 2010, registration No. 16231)
} 
not always willing to join in the hearing: someone is on the phone, someone has an absent gaze.

A speech is a complex pseudo-scientific text, which, as a rule, is completely displayed on the slides, as if the school did not teach to highlight the main thing, the essence, the supporting words. Everything is observed, students pronounce the correct texts, but the process unfolds formally. In the absence of constant technical support, the teacher's main goal is to awaken the interest, involvement, and emotions of the audience. Yes, this is not always possible, but such interaction is satisfying for both sides of the educational process. And how much effort had to be made to involve young people into the discussion, to teach them how to find illustrations, examples of confirmation or refutation of theories, models, theses from the facts of their own life or what they saw with their own eyes, and not to retell the textbook.

The dampening effect of electronic help was also clearly reflected on me, when on the eve of the lecture, instead of thinking over the material, getting ready, sometimes the thought arose that if I didn't have time, it wouldn't matter, there was an electronic cheat sheet and, pushing away from it, I remember some example ... But these are the observations of a teacher who received a contrasting "technological shower", but how do students themselves, future psychologists, relate to digital technologies?

\section{Research results}

From March 1 to March 3, 2021, a written survey was carried out, in which 50 people took part - students of the 3rd and 4th courses of the directions of psychology and conflictology, that is, almost all students.

It turned out that on an average a day 3 people spend up to 4 hours in front of the screen of various technical devices (personal computer, laptop, tablet, smartphone), from 4 to 6 hours - 10 people, from 6 to 8 hours - 15 people, from 8 to 10 hours - 13 people, from 10 to 12 hours - 5 people, over 12 hours - 4 people. This did not take into account the time in the classroom, i.e. in fact, this figure is even higher. In other words, almost half of the humanities students (22 people) spend more than eight hours working in front of the screens. It takes less than 2 hours to study directly for 8 people, 2-3 hours - for 17 people, 3-4 hours - for 12 people, over 4 hours - for 13 people. Half of the students ( 25 people) spend more than 3 hours to prepare for the classes. Of these, 6 respondents believe that they spend more than 7 hours a day on the study.

At the same time, only a little more than a third of the sample - 18 people - have a $100 \%$ level of vision. Out of 32 students with reduced visual acuity, three of them reach $-6,-7,-$ 8.5 , in two, myopia is accompanied by astigmatism. About half ( 23 people) reported a decrease in visual acuity during the training, which was especially evident during the period of distance learning. "My eyes began to get tired very quickly," “-1.5 for training," - these are their comments.

According to the data obtained, the overwhelming majority of students (46 people) use different types of electronic assistants - most often its a laptop/computer and a smartphone. Some have a tablet added to this. But as it turned out, 4 students have only a smartphone.

The majority of students - 30 people write lectures in a notebook. 16 people use a combined method, using a phone or laptop, and 4 people take notes very rarely. Less than a half of the respondents consider their handwriting to be beautiful - 22 people: it is clear, neat, readable, understandable, with flowers, cute, restrained, pleasant, mathematical, ordinary, even, natural, feminine, spontaneous, refined. In the opinion of more than a half of the respondents (26 people), their handwriting is ugly: it is illegible, clumsy, hasty, twisting, chaotic, lively, scattered, strange, practical, careless, peculiar, prancing, 
unfinished, jumping, incomprehensible, crooked, chaotic, winding, shallow, and someone writes horribly. Two people think that sometimes they write beautifully, and sometimes not.

31 people prefer to use literature in the paper format, 14 people in the electronic format and 5 people have no preferences. At the same time, 38 people mainly use sources in the electronic form, 10 people use different formats in equal proportion, and 2 people, preferring electronic media, mostly use paper ones.

More than three-quarters of students in psychological fields (39 people) believe that the digital technologies used in the educational process at FEFU are sufficient. Almost everyone writes about the need to constantly update computers, and faster Internet without interruptions. "You don't need anything. It works well "," At times it is even too much, "they say. And there is even a remark: "Appropriate. But there should not be too much: there are teachers who neglect the live delivery of the lectures. The interest is lost."

Less than a quarter (11 people) reported that they would also like to see the timetable in the form of electronic boards; a convenient electronic database of textbooks; a relaxation room with the feedback; virtual reality and holograms in the study of anatomy, physiology, neurophysiology; and also to have an opportunity to study with the foreign specialists remotely.

It was impossible to get around the issues related to the attitude to digital-based distance learning, which was introduced throughout Russia on March 16, 2020. The students studied distantly only a part of the spring semester, in the fall of the new academic year FEFU started the live training, but at the end of November, this form was cancelled again. At first, the reason was an emergency: after a strong and prolonged freezing rain, the shrouds of the bridge to the Russian island, where the university is located, were covered with ice. And then again there was an increase in the number of cases of a new corona-viral infection. And only from February 22, 2021, the university started to work as usual.

The students answered the two open-ended questions: the pros and cons of online learning. To generalize the answers, the following semantic units were singled out: organizational factors, the quality of training, psychophysiological characteristics, social interaction, the emotional component, and the technical component.

Table 1. Pros and cons of distance learning according to psychology and conflictlogy students

\begin{tabular}{|c|c|c|}
\hline Sense units & Pros & Cons \\
\hline Organizational factors & $\begin{array}{l}\text { Saving time at training camps, on the } \\
\text { road, saving money, it is convenient to } \\
\text { combine training with work and } \\
\text { household chores, there is an } \\
\text { opportunity to attend classes during } \\
\text { illness, a study from anywhere in the } \\
\text { world, more free time, easier to plan } \\
\text { the day, less contact with the strangers }\end{array}$ & $\begin{array}{l}\text { You are often distracted by the others, lack of } \\
\text { the equipment and place to study, too much } \\
\text { time working with electronic media, many } \\
\text { cheat, an increase of the homework and } \\
\text { independent study of the material }\end{array}$ \\
\hline Quality of teaching & Easier to answer, easier to cheat & $\begin{array}{l}\text { There is little opportunity to discuss } \\
\text { incomprehensible material with the teacher, } \\
\text { low self-control, lack of external control, } \\
\text { insufficient understanding of tasks and their } \\
\text { conditions, poorly assimilated material - no } \\
\text { eye contact with the teacher, inability to gain } \\
\text { practical knowledge (mediation, negotiations, } \\
\text { counselling, training), low motivation to } \\
\text { study, more negligent attitude towards } \\
\text { studies }\end{array}$ \\
\hline $\begin{array}{l}\text { Psychophysiological } \\
\text { characteristics }\end{array}$ & Less stress, you can eat normally & $\begin{array}{l}\text { Fatigue, stress due to a constant presence in } \\
\text { front of the PC, decreased activity, sedentary } \\
\text { lifestyle, backaches, eyes ache / tired, work } \\
\text { without going out into the fresh air, loss of } \\
\text { concentration due to the monotony of } \\
\text { actions, it is difficult to concentrate and not } \\
\text { be lazy, you become too relaxed }\end{array}$ \\
\hline
\end{tabular}




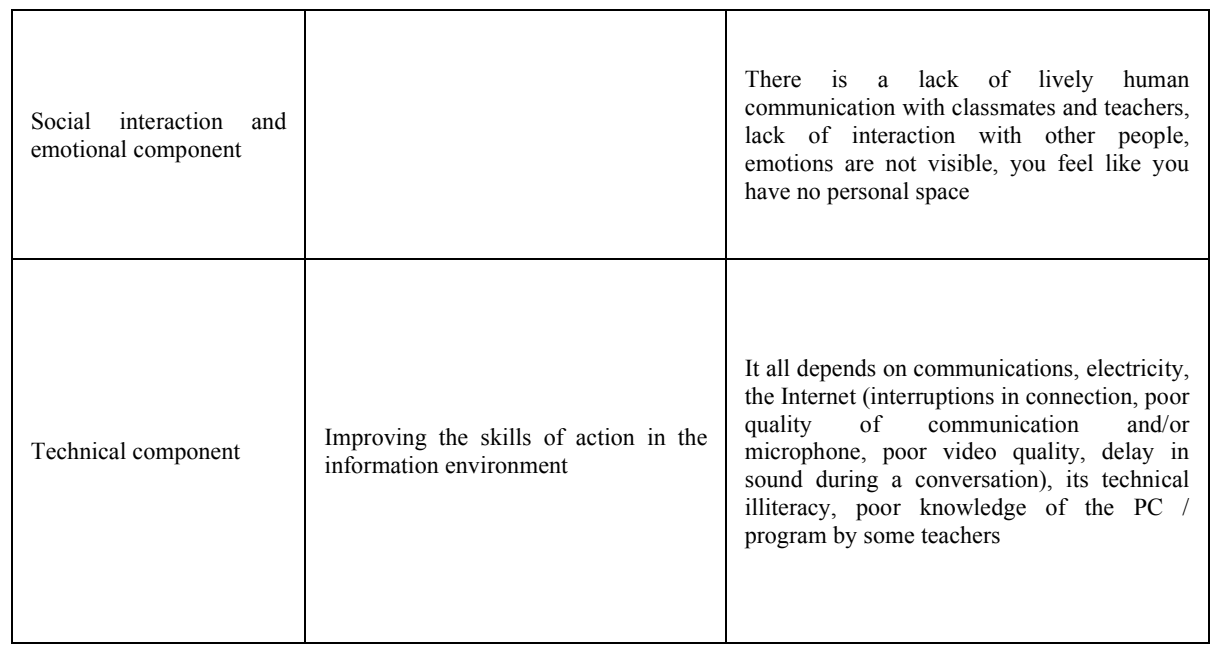

So, the positive side of distance learning (table 1) for young people is associated with the organization of the learning process: this form allows you to combine the study with your business. This is the most common argument, used by almost everyone. Moreover, students frankly associate the convenient organization of the educational process and the pace of work with the fact that you can sleep longer, to the extent that you don't have to get out of bed at all, you can record a lecture, and be in a cosy atmosphere at home. At the same time, the quality of training and the physiological component is represented by single, rare arguments.

As can be seen from the table, there are much more disadvantages of distance learning according to students. Arguments related to the quality of teaching and the assimilation of the material are in the first place in terms of the number of repetitions. Social interaction and the emotional component lose, and for the humanities, these are important components of professional activity. The problematic psycho-physiological component is manifested because sometimes they do not go away from the computer all day long. Almost all respondents note the technical component as a minus. Also, the students trained in reflection have noticed the signs of addiction, the formation of dependence on the Internet, this is an integral characteristic that was not included in the table.

Almost a sixth of the respondents (8 people) wrote that it was difficult for them to learn, in this format they see only disadvantages. "No communication, no socialization, no motivation", "Digital electronic will not replace the living", "The sense and taste of the university time are lost". One good student frankly admitted that for her it is direct harm to her vision: "My eyes hurt a lot and it's very hard to spend so much time in front of the screens". Three, on the contrary, are definitely in favour and are ready to continue studying online further.

\section{Discussion and conclusions}

Using the example of one city, we can state that the intensity of the use of digital technologies in one area of study in different universities differs significantly. The overwhelming majority of students of psychology and conflictlogy at the Far Eastern Federal University have enough information technology. Moreover, they felt the value of the electronic educational environment during the period of distance learning, when everyone turned out to be participants in a forced covid experiment. 
Students and teachers have successfully mastered the Teams and coped with this situation quite well. Since then, this information platform has become an additional learning technology and a backup option, because, as experience has shown, we are not immune to the repetition of unforeseen situations of various origins. The problems that arose, in this case, are consonant with what was happening in the other countries in organizational terms (mastering new training platforms, constant e-mailing in all situations, telephone contacts, the increased load on the Internet networks), in the social, and emotional (Lokanath, M., Tushar, G., Abha, S. 2020) [10]. The survey also revealed that there is a small number of students who do not have personal electronic media with a large screen, there are those who did not have a workplace at home, as a result, difficulties arose during the period of online learning. This problem remains open.

The screen information load cannot grow indefinitely, and this is demonstrated by the gap between the preference for the traditional paper format of books and the fact of using electronic books, which are more accessible. This is a probabilistic factor of a decrease in visual acuity in almost half of the students, which requires a targeted study. The total time spent by the students of the humanities in Vladivostok in front of the screens of various technical devices is comparable to the results of the study of Volgograd Technical University students [11]. The revealed psychological aspects of the educational environment functioning can be useful in other areas of training.

An important component of the educational process is the possibility of giving education to people with reduced vision and its complete absence. At the University of Victoria in Wellington (New Zealand), this is a transition to a new paradigm for supporting visually impaired students (Pacheco, E., Lips, M., Yoong, P., 2018) [12]. At the Far Eastern Federal University, the process is supervised by the employees of a special department, which is bearing fruit: last year, a psychologist student with a complete lack of vision successfully defended his final qualifying work in the online format, and now he continues his studies in the magistracy. An important role, as the observation shows, was played by the help and support of those who were around: in the group, he was always among his fellow students, he was treated as an equal. From the outside, looking at the easy communication of young people, it was possible to guess whom it was only by noticing a white cane standing somewhere nearby.

Interactive learning in an online format was seriously hampered by the technical difficulties, as well as by the uncertainty of teachers as users of the new educational platform. At the same time, one can agree with A.A. Strokov, that digitalization can limit the activity of the older generation teachers who can work successfully live [13].

Online courses are being actively introduced into the educational process of full-time education at FEFU. There are already several platforms on which the author's developments of the country's top-rated universities teachers are posted. According to N.B. Kushcheva and V.I. Terekhova, a serious problem of the online form of education is the lack of quality content [5]. In this regard, it should be noted that for full-time education, video lectures that are not competing with the full-time teacher are no longer needed, but the fact that he, due to the limited possibilities of the educational space, either cannot give a lecture, or it is extremely difficult. This applies to anatomy, physiology, neurophysiology, neuropsychology, conducting various kinds of experiments, including those that have already become classics, video recordings of negotiations, conducting the mediation, consulting a real client. Today, the selection of such materials is a personal initiative of the teacher and an endless search on the endless spaces of the Internet.

The use of technical means and visibility is a tradition of Russian education. Back in the 70 s in the twentieth century, all secondary schools were provided with film projectors and a film fund. There were specialized film studios in the country that produced educational and scientific films. With the curtained windows under the monotonous crackle of the Ukraine 
movie projector, the schoolchildren watched complex chemical experiments, experiments with biological material, and so on. In higher education, at present, the task of forming not only lecture content but also full-fledged documentary video films on the issues under study is becoming urgent.

Digital technologies are only a tool, means of delivering content. The main function of university education teaching people to think. The smartest young people study at the federal university, many have wonderful memories, they can easily reproduce scanned text with a glance. But to what extent this text is understood and appropriated is another question. For knowledge not to become an absolute introject, efforts, work, the discussion is needed, this can be done only in direct communication. The second component of the process is the ability to express your thoughts, and for this, you need to talk more. The main role of a modern higher education teacher, I think, is to create conditions for the transition from reproduction to critical comprehension and independent thinking. It is impossible to do this without direct interaction, emotional involvement, and it is impossible without contact learning.

In the professional environment, the opinion is often expressed that digital technologies are a necessary but insufficient condition for increasing the training effectiveness (N.Sh. Kozlova, 2019) [14]. training should be based on the universal values and preserve the unique socio-cultural code of the nation (OV Gordienko, AA Sokolova, AA Simonova, 2019) [15]. This must not be just a point of view, but a living reality.

\section{References}

1. O.F. Prirodova, A.V. Danilova, A.N. Morgun, The structure of the digital educational environment: regulatory and methodological aspects. Pedagogy and Psychology of Education 1, 9-30 (2020) DOI: 10.31862 / 2500-297X-2020-1-9-30

2. D.G. Kochergin, E.E. Zhernov, Experience of digitalization of higher education in the USA. Vocational education in Russia and abroad 2(34), 12-22 (2019) URL: https://cyberleninka.ru/article/n/opyt-tsifrovizatsii-vysshego-obrazovaniya-vssha/viewer (last accessed: 2021/02/20)

3. N. C. Khin, Integration of Technology in Higher Education in Myanmar: A Review of University Teachers' Perceptions of Barriers and Supports. Technium Social Sciences Journal 15(1), 89-98 (2021) URL: https://techniumscience.com/index.php/socialsciences/article/view/2219 (last accessed: 2021/06/03).

4. Jon-Chao Hong, Hsien-Sheng Hsiao, Po-Hsi Chen, Chow-Chin Lu, Kai-Hsin Tai, ChiRuei Tsai: Critical attitude and ability associated with students' self-confidence and attitude toward "predict-observe-explain"online science inquiry learning. Computers \& Education 166 (2021) URL: https://doi.org/10.1016/j.compedu.2021.104172.

5. N.B. Kushcheva, V.I. Terekhova, Modern digital educational environment in higher education in Russia. Problems of Science and Education 1, 191-194 (2018) URL: https://cyberleninka.ru/article/n/sovremennaya-tsifrovaya-obrazovatelnaya-sreda-vvysshem-obrazovanii-rossii/viewer (last accessed: 2021/06/03).

6. Y.V. Sharonin, Digital technologies in higher professional education: from personcentred SMART didactics to blockchain in targeted training of specialists. Modern problems of science and education 1 (2019) URL: http://scienceeducation.ru/ru/article/view?id=28507 (last accessed: 2021/06/03) 
7. N.P. Lysikova, L.P. Zhurbina, Features of the Korean education system: traditions and innovations. Collection of scientific articles 14, 91-96 (2019) URL: https://www.elibrary.ru/item.asp?id=41305500\&pff=1 (last accessed: 2021/02/20)

8. A.N. Gusev, K.R. Kashfullina, K.A. Nasonov, Reforms of higher education in China and the Republic of Korea: the use of foreign experience in the modernization of the system. Bulletin of International Organizations: Education, Science, New Economy 1(9), 124-149 (2014) URL: https://cyberleninka.ru/article/n/reformy-vysshegoobrazovaniya-v-kitae-i-respublike-koreya-ispolzovanie-zarubezhnogo-opyta-vmodernizatsii-sistemy (last accessed: 2021/02/20)

9. E.M. Severina, Humanitarian technologies in the digital age. Philological sciences. Questions of theory and practice 12(90), 381-385 (2018) URL: https://cyberleninka.ru/article/n/gumanitarnye-tehnologii-v-tsifrovuyu-epohu ( last accessed: 2021/02/21)

10. M. Lokanath, G. Tushar, S. Abha, Online teaching-learning in higher education during the lockdown period of COVID-19 pandemic. International Journal of Educational Research Open 1 (2020) https://doi.org/10.1016/j.ijedro.2020.100012

11. R.M. Petruneva, V.D. Vasilyeva, Yu.V. Petruneva, Modern students: digital existence. Pedagogy and Psychology of Education 2, 150-160 (2020). DOI: 10.31862 / 2500297X-2020-2-150-160

12. E. Pacheco, M. Lips, P. Yoong, Transition 2.0: Digital technologies, higher education, and vision impairment. The Internet and Higher Education 37, 1-10 (2018) URL: https://doi.org/10.1016/j.iheduc.2017.11.001.

13. A.A. Strokov, Digitalization of education: problems and prospects. Minsk University Bulletin 2(8), 15 (2020) URL: https://cyberleninka.ru/article/n/tsifrovizatsiyaobrazovaniya-problemy-i-perspektivy (last accessed: 2021/06/03).

14. N.Sh. Kozlova, Digital technologies in education. Bulletin of Maykop State Technological University 1(40), 83-91 (2019) DOI: 10.24411 / 2078-1024-2019-11008

15. O.V. Gordienko, A.A. Sokolova, A.A. Simonova, Axiological characteristics of the digital transformation of education. Pedagogy and Psychology of Education 3, 9-21 (2019) DOI: 10.31862 / 2500-297X2019-3-9-21 